\title{
ECONOMIC EVOLUTIONS DURING THE COLD WAR - ROMANIA IN THE COMECON (1949-1965)
}

\author{
Cristian Bențe* \\ "Vasile Goldiș, Western University of Arad, Romania \\ E-mail: cristianbente@uvvg.ro
}

(Received: July 2020; Accepted: September 2020; Published: October 2020)

\begin{abstract}
The purpose of this work is to present objectively and documented the evolution of Romania within the Council of Mutual Economic Aid (C.M.E.A. or C.O.M.E.C.O.N.) during 1949-1965. Choosing this period of time is not random: in 1949 COMECON was established at the initiative of Moscow, and the year 1965 represented the peak of the "dissidence" politics of Romania within the Council. The Romanian economy after the Second World War followed largely the same path as the other economies in Eastern Europe that entered the sphere of influence of the Soviet Union. The war and the new international situation in which Romania found itself at its end determined a dramatic rupture with the economic model followed in the interwar period. In the run-up to the end of the world conflict, the main interest of the hegemonic power in Eastern Europe, the Soviet Union, was to benefit from the resources of the countries in the area to compensate for the immense damage caused by the war. The exploitation of Eastern European economies intensified after Moscow became aware of the impossibility of obtaining substantial war reparations from Germany.
\end{abstract}

Keywords: centralization, nationalization, planning, industrialization, foreign trade.

JEL Codes: F13, F15, F53

\section{Introduction}

The evolution of Romania within COMECON can be divided into three main phases: the first one (1949-1953) represented "the golden age" of COMECON. During this period, Romania did not involve consistently into the problems of the Council. In the second phase (1954-1959), Romania participated at the effort of constructing an institutional structure for COMECON, hosting a number of specialized commissions, and organizing two COMECON sessions. The Romanian

\footnotetext{
* Corresponding author: Cristian Benţe. E-mail: cristianbente@uvvg.ro

Copyright $(C 2020$ The Author(s). Published by VGWU Press

This is an Open Access article distributed under the terms of the Creative Commons BY 4.0 license (Creative Commons - Attribution 4.0 International - CC BY 4.0) which permits unrestricted use, distribution, and reproduction in any medium, provided the original author and source are credited.
}

132 Sciendo Studia Universitatis "Vasile Goldis" Arad. Economics Series Vol 30 Issue 4/2020 ISSN: 1584-2339; (online) ISSN: $2285-3065$

Web: publicatii.uvvg.ro/index.php/studiaeconomia. Pages $132-145$ 
Bențe, C., (2020)

Economic evolutions during the cold war-Romania in the COMECON (1949-1965)

delegates are present at the Council meetings where they take position and make recommendations. During this period Romania takes more seriously its role in the COMECON structures. In the third phase (1959-1965) Romania manifests its opposition within COMECON by voting against certain initiatives, abstaining and even refusing to sign several resolutions and recommendations of COMECON.

\section{Literature review}

In order to reconstitute as correctly and objectively as it is possible the evolution of the relations of Romania with the partner states from COMECON, I appealed to multiple sources: firstly to the documents from the Central National Historical Archives, more precisely to the documents from the fund dedicated to the works of the Central Committee of PCR, as well as to the archive fund of the Government Commission for the problems of COMECON; secondly I consulted the economic journals ("Economic Problems", "Agricultural Problems", "The Economic Life") and the official statistics published during that period (especially the Statistical Yearbooks); thirdly I consulted the specialized bibliography published both abroad (mainly the works of Michael Kaser, Frederic L. Pryor, Jozef van Brabant, Nicholas Spulber and John Michael Montias) and in Romania (as those of Ion Alexandrescu, Maria Curteanu, Liviu Ţăranu).

\section{Research methodology}

This study is focused on analyzing the economic relations of Romania with the other member states of COMECON, during 1949-1965. In order to achieve this goal I accessed mainly the economic data offered by the Romanian archive documents. The data that were obtained are extensive and relatively accurate. However, a further study of the Russian archives would provide a more comprehensive and objective outlook on the economic relations within COMECON during the above mentioned period of time.

\section{Findings and discussion}

\subsection{The international context of the establishment of COMECON} The evolution of the relations between USSR and the Eastern-European countries before and after the Second World War

The victory of the Bolshevik Revolution from Russia that began in 25 October/7 November 1917, led to the emergence of a new actor on the international stage: the Soviet Union. The entire history of the Soviet regime stood under the sign of uncertainty, in fact of a double fear: that of the enemy from inside and that of the enemy from outside. 
Bențe, C., (2020)

Economic evolutions during the cold war-Romania in the COMECON (1949-1965)

Although the Bolsheviks were victorious inside, they still feared the „capitalist encirclement". The only solution seemed to be the triggering of a world revolution. During 1919-1924 the Communist leadership from Moscow tried to secure the Soviet borderland by "exporting revolution". After the unsuccessful actions in Poland, Romania and Estonia, the Russians had to admit the failure of this strategy. The fear of the „capitalist encirclement”, doubled by the serious problems from within, generated at Moscow a "thirst" for security that manifested in the exterior through the effort of settling a protective space at the borders of URSS. Stalin, as a realist in the International Relations, considered a priority the installation of communist regimes in the neighboring countries that would facilitate a possible intervention of the Red Army "to help the revolution" (Volkogonov, 1994).

The establishment of a buffer zone under the Soviet protection became a reality after the initialization of the Soviet-German agreements of 23 August 1939 (also known as the Molotov-Ribbentrop Pact) and 28 September 1939 (The Treaty of Friendship and Border). Following these treaties with Nazi Germany, in 1939 and 1940, the Soviet Union pursued to the annexation of certain parts of Poland, Finland, Romania as well as the Baltic States (Estonia, Latvia and Lithuania).

The launch of the German attack on 22 June 1941 forced the Soviet Union to abandon the territories that Stalin got after the agreements with Hitler. From that moment, one of the main objectives of the Soviet leader was to obtain the recognition of these territorial acquisitions from his new allies, Winston Churchill and F.D. Roosevelt.

The first reaction of the Western leaders was to reject Stalin's propositions as they previously declared that they would not recognize the territorial changes made by force during the war. After the battle of Kursk (5 July - 23 August 1943) when the Soviet Union gained strategic initiative, the Westerners began to understand the magnitude of their mistake.

Alarmed by this situation, Churchill initiated negotiations with the Soviets in order to establish the zones of influence "between the powers". These negotiations will be finalized at Moscow, during 9-18 October 1944, with the percentage agreement between Stalin and Churchill. According to this, the Soviet Union would gain preponderance in Romania (90\%) and Bulgaria (75\%), would be at equality with the Great Britain in Yugoslavia and Hungary, whereas the British would have preponderance in Greece (90\%) - (Zorgbibe, 1994).

Moscow installed their control over Eastern Europe since 1945. At the same time, there was increasing tension between the Soviets and their Western allies. This tension would end up in a new kind of conflict: the Cold War. A turning point in this conflict was the rejection of the Marshall Plan by the Soviet Union.

The establishment of the COMECON in January 1949 was one of the measures taken by Moscow in order to counteract the effects of the Marshall Plan and to

134 sciendo Studia Universitatis "Vasile Goldis" Arad. Economics Series Vol 30 Issue 4/2020 ISSN: 1584-2339; (online) ISSN: $2285-3065$

Web: publicatii.uvvg.ro/index.php/studiaeconomia. Pages $132-145$ 
Bențe, C., (2020)

Economic evolutions during the cold war-Romania in the COMECON (1949-1965)

consolidate the Soviet influence in the satellite-states from Eastern Europe. This measure was preceded by other actions meant to strengthen Moscow's political, economic and ideological control over these states.

4.2. The "integration" of the Eastern-European economies into the Soviet system at the end of the Second World War and their transformation in state, centralized, and planned economies

The integration of the Eastern-European states into the Soviet Union's sphere of influence at the end of the Second World War represented a complex process that aimed all the vital sectors in those states. In a relatively short period of time, the political, economic, social and cultural life of the Eastern-European states was radically transformed, according to the models imposed by Moscow.

The Soviet Union imposed its control over Eastern Europe because it had strategic, political, military and economic interests in this region. The states in this region became, after the Soviet Union broke relations with its former Western allies, the main suppliers of resources for the recovery of the soviet economy. The soviet control over the Eastern-European economies took many forms: from the brutal transfer of raw materials, finite products and technology during the first years after the war, to more subtle methods, as the establishment of "mixed enterprises", the initialization of bilateral agreements and finally by establishing the COMECON. Through these diverse means, the economic pressure of the Soviet Union, although moderate, it was truly overwhelming for the Eastern-European states by the death of Stalin. Certainly, the Soviet Union did not succeed in "integrating" the EasternEuropean economies, nor in synchronizing them perfectly with its own economy, but it certainly succeeded in reducing them to a state of industrial dependence. Thus, during 1950-1956, Czechoslovakia imported from USSR $70 \%$ of its necessary of copper and aluminum, $75 \%$ of iron ore, $80 \%$ of oil, $90 \%$ of nickel; Poland $-43 \%$ of grains, $49 \%$ of hydrocarbons, $64 \%$ of iron ore, $81 \%$ of cotton etc (Pollard: 1985).

\subsubsection{The agrarian reforms and the collectivization}

The sector that undertook the most radical transformations was the agriculture. The process of transforming Eastern-European agricultures can be divided into two large periods: (1) the period from 1945 to $1948-1949$ when a series of measures of agrarian reform were taken; (2) the period after 1948-1949 when the collectivization process began. During the first period there were introduced radical agrarian reforms that led not only to division of great land properties but also to the portioning of certain lands that were already subdivided, as it was the case in Romania. 
Bențe, C., (2020)

Economic evolutions during the cold war-Romania in the COMECON (1949-1965)

Despite the efforts to impose collectivization, the results of this process were not those expected. Thus, in 1955, only one country could "boast" with a high percentage of collectivized lands: Bulgaria, with $61 \%$. The other countries were oscilating between a third (Czechoslovakia: 29\%) and a fifth (Hungary: 22\%). Romania (13\%) and Poland (11\%) barely exceed $10 \%$.

Table 1 The percentage of arable land collectivized in different eastern european countries (1945-1954)

\begin{tabular}{|c|c|c|c|c|c|c|c|c|c|c|c|}
\hline Country & $\mathbf{1 9 4 5}$ & $\mathbf{1 9 4 6}$ & $\mathbf{1 9 4 7}$ & $\mathbf{1 9 4 8}$ & $\mathbf{1 9 4 9}$ & $\mathbf{1 9 5 0}$ & $\mathbf{1 9 5 1}$ & $\mathbf{1 9 5 2}$ & $\begin{array}{c}\text { June } \\
\mathbf{1 9 5 3}\end{array}$ & $\begin{array}{c}\text { Dec } \\
\mathbf{1 9 5 3}\end{array}$ & $\begin{array}{c}\text { Dec } \\
\mathbf{1 9 5 4}\end{array}$ \\
\hline Bulgaria & 3.0 & 3.5 & 3.7 & 6.2 & 11.3 & 43.0 & 47.5 & 51.0 & 51.7 & 51.7 & 51.7 \\
\hline Czechoslovakia & n.a. & n.a. & n.a. & n.a. & 5.4 & 16.5 & 19.0 & 37.9 & 40.0 & 38.0 & 33.0 \\
\hline Hungary & n.a. & n.a. & n.a. & n.a. & 0.5 & 2.6 & 8.1 & 18.2 & 24.6 & 20.0 & 18.0 \\
\hline Poland & n.a. & n.a. & n.a. & n.a. & 0.3 & 2.2 & 3.5 & 4.8 & 6.7 & 6.7 & 8.5 \\
\hline Romania & n.a. & n.a. & n.a. & n.a. & 0.1 & 2.7 & 3.1 & 7.2 & 7.5 & 7.5 & 11.0 \\
\hline
\end{tabular}

Source: Spulber (1958)

\subsubsection{The politics of nationalization}

If the agrarian reforms and then the collectivization process were introduced gradually, requiring great efforts from the East-European Communist leaders; the nationalization of the bank system, of the foreign trade, of the energy sources, of transports and of the main industries raised just minor problems and generated less resistance than the collectivization. One of the reasons was that in many European countries (Germany, Czechoslovakia, and Poland) and from Asia (Korea, China) the economic structures were already largely confiscated by the Germans or the Japanese, so that nationalization was easily imposed after the war. Furthermore, some governments operated nationalizations even before Communists took power. Thus, in Eastern Europe, in most of the cases there were the "national front" governments (dominated by Communists) that initiated the main nationalizations. The nationalization process developed slower in the countries ex-allied of Germany (Romania, Hungary, and Bulgaria), the main cause for this being the Soviet seizure over the German goods, but also the fact that the interwar social and economic structure was better preserved here than in the countries that were allied of Moscow (Czechoslovakia, Poland and Yugoslavia), where both the German occupation during the war and the "liberating" Red Army fully contributed to the disintegration of the interwar social and economic structures.

\subsubsection{The beginning of centralized and planned era}

Following the model of the Soviet Union, the new Eastern-European regimes completed the nationalization measures by the introduction of certain methods of economic planning. The prototype of centralized and planned economy was developed in the Soviet Union at the end of the 20's as a mean of accelerating the 
Bențe, C., (2020)

Economic evolutions during the cold war-Romania in the COMECON (1949-1965)

industrialization in a relatively backward country. The Soviet model of centralized and planned economy was implemented in the satellite countries from Eastern Europe after the Second World War. The implementation of this model was eased by a series of political factors; among the most important were the presence of the Soviet troops in these countries and the gaining of political power by Communist parties. At the beginning, the government just elaborated short term plans (yearly plans in Romania and Korea; biennial in Czechoslovakia, Bulgaria and Albania; triennial in Poland and Hungary). The main purpose of these plans was to remediate the damages of war, supplying the cities, the reconstruction of the plants and of the communication ways, gradually increasing the production at the prewar level, reducing inflation etc. Although the objectives of these plans were modest, they were just partly fulfilled due to the lack of consistent financing. The finance for these projects should have come from external credits. Due to the lack of these funds, the entire responsibility of fulfilling these plans was attributed to the Eastern European peoples, forced to make enormous sacrifices.

\subsection{The reasons behind the establishment of COMECON from the perspective of the evolution of the International Relations and of the situation within the communized states}

The establishment of COMECON was generally regarded by historians as a fait accompli of the Soviet Union, often ignoring the interests of the Eastern-European states in promoting the regional economic cooperation. It is known the fact that the Eastern-European states displayed an early interest in developing a subregional political and economic cooperation as a solution for their economic and security problems. But the Eastern-Europeans had a completly different image of cooperation than the Soviets. The interwar plans of regional cooperation did not include the Soviet Union. After the Second World War the necessity of cooperation became urgent. But key factor in promoting economic cooperation in the region became the Soviet Union. The main reasons that stood behind the decision of establishing COMECON were the Soviet economic and security interests. Moscow outlined the guidelines for the future evolution of COMECON according to its own interests. Thus, from 1949 to 1953, the COMECON worked according to the Soviet model of autarky and with a feeble institutional structure.

\subsection{The evolution of the economic strategies of the COMECON during 1949- 1965}

\subsubsection{The COMECON during the first years of functioning}

In the first years of its functioning, the COMECON initiated a process of economic development based upon a rapid industrialization. Thus, every member country invested during this period about $40 \%$ of their total investments in industry, 
Bențe, C., (2020)

Economic evolutions during the cold war-Romania in the COMECON (1949-1965)

neglecting the agriculture and the construction sector. Moreover, $80 \%$ of the total investments made in industry were dedicated to "heavy industry". The trade relations of the member states with the Western partners decreased dramatically in favor of the intra-bloc relations. The results of these policies were several expensive and unprofitable projects, a great number of parallel investments in the member countries, but also a profound crisis of raw materials and basic products.

\subsubsection{Attempts of revitalizing the COMECON. The beginning of specialization within the Bloc (1953-1960) \\ The first „relaunch”, 1954-1956}

After Stalin's death in March 1953 there were several attempts to "revitalize" COMECON activity, to put it on a more equitable base and to start use it as a substitute for the more direct methods to dominate Eastern Europe that were employed by the Russians until then.

The Session of the Council from March and June 1954 settled a permanent Secretariat and a permanent Conference of the representatives of the member states. During these meetings there were also initialized a series of "agreements for specialization", meant to reduce the economic costs of parallel investments and the lack of imports, and in 1956 there were established ten Permanent Commissions that had to coordinate the specialization and the cooperation in certain economic sectors. The Sessions of the Council in December 1955 and May 1956 focused mainly on the coordination and synchronization of the five years national plans. In reality, most of the attempts of plan coordination in this period were merely bilateral and narrowed to the commercial implications of the national plans. As for the "agreements for specialization" from 1954-1956, these were largely cancelled by the social and political uprisings of 1956 that imposed new ad-hoc priorities meant to abate the economic dissatisfaction.

\section{The second „relaunch”,1957-1960}

The COMECON knew a second "relaunch" following the events of November 1956 in Hungary. The Council Plenum of December 1959 adopted with a delay the Constitutional Chart of COMECON that was inspired by the well-known Treaty of Rome (1957). The Chart defined the statute and the functions of: the Session of the Council ("the highest organ"), the Executive Committee ("the main executive organ"), the Permanent Commissions and the Secretariat. The main purpose of these institutions was to promote "the consistent implementation of socialist international division of labor". The supranational implications of this new orientation opened a more substantial chapter in the history of COMECON, but it also seeded dissension within it. 
Bențe, C., (2020)

Economic evolutions during the cold war-Romania in the COMECON (1949-1965)

4.4.3. The implementation of the socialist international division of labor at the beginning of the ' $60 \mathrm{~s}$

During the ' $60 \mathrm{~s}$, the East-European economists and reformers began to understand that the foreign trade was a major mean of stimulating economic growth. The Session of the Council of December 1961, in an attempt to keep up with the Western economic growth and integration, but especially at Moscow's orders, approved "The Basic Principles of Socialist International Division of Labor". The main objectives of these Basic Principles were: to stimulate economic growth, higher living standards, industrialization, attenuating the historical economic differences between the member states. The main way to achieve these objectives was "the coordination of the economic plans". However, the member states did not forced themselves to implement these principles, many of them, as Czechoslovakia, Hungary, Poland, and especially Romania, opposed fiercely to the plans of labor division within the bloc.

\subsection{The impact of the establishment of the COMECON upon the economic and foreign policy of Romania during 1949-1965}

\subsubsection{The Romanian economy during 1945-1948: entering Moscow's orbit The Romanian-Soviet Treaty of commerce and economic collaboration on 8 May 1945}

The Stalinization of the Romanian economy that occurred after the Communists gained political control over Romania, involved its transformation after the model of the Soviet economy. That implied the liquidation of the lasts remains of capitalist economy and the imposition of the state, centralized and planned type of economy. This process of transformation and submission of the Romanian economy to the Soviet interests began by the conclusion of the Romanian-Soviet Treaty of commerce and economic collaboration on 8 May 1945. After the negotiations in Moscow between the Romanian delegation led by Mircea Durmă, the Minister of Finance and the Soviet delegation led by A.I. Mikoian, Peoples Commissioner for Foreign Trade on $8^{\text {th }}$ of May the two parts concluded two agreements (one for commerce and exchange of goods and the other for economic collaboration). The economic collaboration aimed especially industry and agriculture. USSR wanted to participate in oil and metalliferous prospections, but at also in timber industry, air and see transportation, bank trade etc. There were established the following collaboration methods: either by exploiting enterprises or other structures that were already functioning, or by creating new joint ventures that were to be directly endowed with concessions and exploitations (the future Sovroms). Very important was the confidential protocol that stipulated that in the next two months would be set up a Romanian-Soviet joint venture in the oil 
Bențe, C., (2020)

Economic evolutions during the cold war-Romania in the COMECON (1949-1965)

industry. Romania was to participate at prospections of free, new lands on the basis of a list commonly agreed upon by both governments, and benefit by $50 \%$ of royalties. Soviet Union was to deliver the necessary equipment.

\section{The establishment of the Sovroms}

One of the first consequences of the Romanian-Soviet Treaty of commerce and economic collaboration of 8 May 1945 was the establishment of Soviet-Romanian joint ventures, the Sovroms. The first convention between the Soviet and the Romanian government for the establishment of the Soviet-Romanian Society of Oil was concluded in 17 July 1945. In the following years other Sovroms were established: Sovromtransport, Sovrombanc, Sovromlemn, Sovromfilm, Sovromcărbune, Sovrommetal, Sovromconstrucţii, and Sovromasigurare. The last Sovroms were established in 1952: Sovromutilajpetrolier, Sovromnaval, and Sovromcuarţ. The activity of the Sovroms can be divided into two periods. The first one lasted during 1945-1948 and is characterized by the total submission of the Romanian part, which did not refuse any of the requests that came from Moscow; and the second one 1948-1956 when Romanians tried to introduce equality and equity in the relations with the Soviet Union. After 1954, the Sovroms were gradually abolished, as they turned out to be extremely unprofitable

\subsubsection{The position of Romania within COMECON in its early years of existence (1949-1953)}

In this early period of the COMECON, Romania followed obediently the economic direction imposed by Moscow. The Romanian economy undertook a process of nationalization, centralization, planning and forced industrialization, following the model of the Soviet Union. Thus, the investments in the industrial group A (heavy industry) grew from 37, 6\% in 1949 to 1951 and 54, 8\% in 1953, whereas the investments in the industrial group B (light industry) dropped continously from $8 \%$ in 1949 , to $5,2 \%$ in 1951 and 4, $9 \%$ in 1953. The lack of raw materials for the new industrial objectives was compensated by massively importing from USSR. The major investments in heavy industry led to an unbalance in the weight of the industrial production, consumer goods and the internal request being totally neglected, whereas the investments in agriculture would start only after 1953.

\subsubsection{The changes of the year 1953}

A new trend in economic politics started to be implemented since 1953. At the same period began the first negotiations for abolishing the Sovroms, and Gh. Gheorgiu-Dej made the first statements regarding "a new type of relations" between the countries of the bloc and the Soviet Union. The main cause for this change in the economic policy is the attempt of the new Soviet leadership to

140 Sciendo Studia Universitatis "Vasile Goldis" Arad. Economics Series Vol 30 Issue 4/2020 ISSN: 1584-2339; (online) ISSN: $2285-3065$

Web: publicatii.uvvg.ro/index.php/studiaeconomia. Pages $132-145$ 
Bențe, C., (2020)

Economic evolutions during the cold war-Romania in the COMECON (1949-1965)

prevent social tensions within the bloc due to poor living conditions. In Romania, the economic situation requested a rapid change. During the meeting between the Romanian and the Soviet leadership that took place in 8-13 July 1953 at Moscow, the Soviets criticized the Romanians for their mistakes in economic policy, mainly for overrating the heavy industry and neglecting agriculture and the other industrial branches. The Romanian Communist leadership began since the end of 1953 to take a set of measures in order to stimulate the production in agriculture and to ensure social protection. However, the industrialization remained a high priority for the Romanian Communist leaders.

4.5.4. Foreign trade of Romania in the first decade of existence of COMECON An important aspect of the transformation of the Romanian economy after the Second World War was the etatization of the foreign trade. The state monopoly over foreign trade was instituted by the Decree of 28 July 1949 . According to this act the Ministry of Foreign Trade seized to grant authorizations to private enterprises for operations of foreign trade. Becoming a part of a centralized economy, the foreign trade had to be planned. As for the geographical repartition and the volume of foreign economic exchanges, the Soviet Union and the other COMECON countries became the main economic partners.

\subsubsection{The position of Romania within the sessions of COMECON during 1949-1959}

During the decade 1949-1959, Romania did not have a major contribution within COMECON. Moreover, it did not take part into several agreements of COMECON. However, Romania satisfied the import needs of many countries within COMECON. The main Romanian products that were exported were oil products, timber, food products, construction materials and machines, especially for the oil industry, chemicals etc. Following the recommendations of the $7^{\text {th }}$ session of COMECON, Romania specialized in certain processed products: bearings, $4 \mathrm{t}$ trucks, tractors, certain maritime and fluvial ships, oil installations, rail trucks. After covering the internal demands, Romania exported these products in the Soviet Union, RDG, and Czechoslovakia.

\section{The elaboration of the Statute of COMECON. The organizational structure of COMECON}

During 10-14 December 1959 took place one of the most important Sessions $\left(12^{\text {th }}\right)$ of the Council, at Sofia, when it was adopted the first adopted the first Statute of the COMECON, after a decade since its foundation. The statute regulates the right and the duties of the COMECON members, finalizes the institutional structure of the Council and determines the main forms of collaboration within COMECON: 
Bențe, C., (2020)

Economic evolutions during the cold war-Romania in the COMECON (1949-1965)

the coordination of national economic plans, the specialization and the cooperation in production, the development of commercial relations. The moment when the Statute of the COMECON was promulgated it was a very important one in the evolution of the Council. Romania did not show a particular interest in this document, considering it just a cumulus of internal rules that were already in place, and the changes brought by the Statute in the activity of the organization were minor.

\section{The incapacity of Romania to respect the recommendations of the COMECON}

Following the recommendations of the COMECON Sessions, Romania tried to put into practice the principles of specialization and cooperation within the bloc. Thus, Romania concluded a series of bilateral agreements with the USSR, East Germany, Poland and Czechoslovakia, regarding the granting of loans in order to build several industrial objectives, as well as the transfer of technology from these states. Unfortunately, these agreements were broken repeatedly, Romania facing major setbacks in acquiring the promised technology, and regarding the quality of the equipment.

\subsection{The romanian ,dissidence” within the COMECON (1959-1965)}

During the first two periods in the evolution of COMECON, the attitude of the Romanian authorities was a submissive one, obeying the decisions of the Council, as long as these were just recommendations.

In the third period that began in the years 1958, 1959, Romania's attitude changed dramatically. The Romanian representatives were making for the first time "divergences", even refusing to sign resolutions that were "unanimously" adopted by the rest of the states. The increasing Romanian opposition towards the attempts of changing the original destination of COMECON (mutual aid and the coordination of commercial relations between socialist countries), reached its peak in 1963-1964 and even in 1965 with a lower intensity.

\subsubsection{A new ideological and economic direction of Romania}

Romania's position in COMECON during 1959-1965 was linked to the favorable evolution of the Romanian economy during this period, as a consequence of the rapid industrialization process initiated by the Romanian authorities since 1950 . The leaders of PMR believed that the only way to progress was industrialization. Thus, in the '60s Romania registered an important economic development, based primarily on massive investment into heavy industry. As a result, the share of heavy industry into the global industrial production grew from $45.5 \%$ in 1938 to $64.5 \%$ in 1963 . Besides the positive aspects of industrialization, the new Romanian

142 Sciendo Studia Universitatis "Vasile Goldis" Arad. Economics Series Vol 30 Issue 4/2020 ISSN: 1584-2339; (online) ISSN: $2285-3065$

Web: publicatii.uvvg.ro/index.php/studiaeconomia. Pages $132-145$ 
Bențe, C., (2020)

Economic evolutions during the cold war-Romania in the COMECON (1949-1965)

industry had multiple flaws: the lack of correlation between production and the internal capacity of energetic resources and raw materials, the lack of specialization in certain industrial fields such as the machine industry.

\subsubsection{The shaping of a separate position of Romania within COMECON}

Major frictions between the members of the Council were registered during the works of the Commissions of COMECON beginning with 1959 and one of the main topics was the industrial specialization.

The Conference of the Communist and Labour Parties in February 1960 held in Moscow was a moment when the Romanian opposition towards specialization manifested openly. During the Conference, several delegates insisted on Romania specializing on agriculture. That was a surprise for the Romanian delegates.

At the end of May 1961, during a visit of a Romanian delegation led by Alexandru Bârlădeanu to Moscow, the Soviets said that Romania "builds an autarkic economy" and "sits on its resources like a clocking-hen on its eggs". Moscow wanted Romania to focus on exploiting raw materials and that was against the wish of the Romanian leaders to deepen the industrialization. Romania also expressed its discontent for the fact that the machine industry was "monopolized" by Czechoslovakia and East Germany that was more advanced in industry.

\subsubsection{The peak of the conflict: the Declaration of April}

The battle of the Romanian Communist leadership for more economic autonomy with the USSR reached its peak with the so-called Declaration of April 1964. This is one of the most important moments in the evolution of Romania within COMECON, the highest point of the Romanian opposition towards an increased control of Moscow over the economies of the bloc. Published in 26 April 1964 in the newspaper "Scânteia", the Declaration consisted of seven chapters; the main theme of the document was about the relations between the Communist and Labor parties that should be founded on new principles, by eliminating the idea of a single international centre of the world Communist movement.

\section{Conclusions and further directions of research}

Immediately after publishing the Declaration, the Romanian authorities initiated a true diplomatic voyage in USA, USSR, France and China. The main purpose of these visits was to prevent any possible violent outbreaks from Moscow. The Declaration was received with interest by the diplomatic circles. Its benefits were immediately felt both inside and outside. Firstly, the psychological effect was direct and very positive in favor of the regime. It was the beginning of an unprecedented relation between the nomenclature and a part of the public opinion. 
Bențe, C., (2020)

Economic evolutions during the cold war-Romania in the COMECON (1949-1965)

After April 1964, Romania knew only a limited democratization. The limits were imposed by the regime itself, the general framework remaining largely the same: a totalitarian society, led by a unique party, with elections on a single list, with censorship etc.

Hence, the evolution of Romania within the COMECON during 1959-1965 was marked by its opposition towards Moscow's attempts to transform the Council in an instrument of control over the national economies of the bloc. The COMECON was an instrument used by Moscow to keep and consolidate its control over the economies of the satellite countries. However, the Council represented a necessary framework for elaborating better commercial policies for the member states and at the same time for getting better exchange conditions for acquiring raw materials and goods from USSR. The Council was a forum for open discussion and debates between the member states. The work of the Romanian representatives within the COMECON structures helped Romania to know closely the economic situation of the other socialist countries. Thus, many of the political and economic decisions taken by the Romanian leadership were based on this information.

\section{Acknowledgments}

The author thanks the anonymous reviewers and editor for their valuable contribution.

\section{Funding}

This research received no specific grant from any funding agency in the public, commercial, or not - for - profit sectors.

\section{Author Contributions}

The entire article was written by Cristian Bențe.

\section{Disclosure Statement}

The author declares no conflict of interest.

\section{References}

1. Banu, F., (2004), Asalt asupra economiei României - de la Solagra la Sovrom (1936-1956), Bucureşti, Ed. Nemira.

2. Bideleux, R., Richard T., (ed.). (1996), European Integration and Disintegration: East and West, New York: Routledge

3. Davis, L., (1974), The Cold War Begins: Soviet-American Conflict over Eastern Europe, Princeton, N.J.: Princeton University Press

4. Gaddis, J.L., (1972), The United States and the Origins of the Cold War, 19411947. New York: Columbia University Press

144 Sciendo Studia Universitatis "Vasile Goldis" Arad. Economics Series Vol 30 Issue 4/2020 ISSN: 1584-2339; (online) ISSN: 2285 - 3065

Web: publicatii.uvvg.ro/index.php/studiaeconomia. Pages $132-145$ 
Benţe, C., (2020)

Economic evolutions during the cold war-Romania in the COMECON (1949-1965)

5. Kaser, M.C., Radice, E.A., (ed.). (1985), The Economic History of Eastern Europe 1919-1975, (vol.1), Oxford: Clarendon Press

6. Pollard, R.A., (1985), Economic Security and the Origins of Cold War, 19451950, New York: Columbia University Press

7. Spulber, N., (ed.). (1958), Collectivization of Agriculture in Eastern Europe, Lexington, KY: University of Kentucky Press 